\title{
Beads and Pendants
}

\section{$1 \quad$ Material Analysis}

The overview of beads (centrally perforated objects) and pendants (objects with off-centre perforation or with attached loop) presented herein follows a classification by material (marine mollusc shell, coral, stone, faience, glass, metal-in-glass, metal) and by the techniques used to make them. Provenance and parallels are provided accordingly.

\subsection{Marine Mollusc Shells}

Two marine mollusc species of Red Sea origin were found: Cypraea annulus sp. and Marginella sp. The former was recorded in five of the tumuli, the latter solely in T.7.

Fifteen complete shells and one shell fragment were identified as Cypraea annulus sp. $\left(\mathrm{Z1} / 27, \mathrm{Z1} / 30, \mathrm{Z}_{4} / 5^{2.1}\right.$ 2, Z7/1, Z7/8.1.1-4, Z7/9.1, Z7/10.1, Z7/79, Z12/2, Z27/5) [Fig. 4.1]. They were perforated by removing the convex part of their bodies, which resulted in a large hole. Similar specimens were discovered in post-Meroitic Tumulus 4 on Uli Island (Godlewski, Obłuski, and Zielińska 2005, Fig. 8). Interestingly, a necklet of cowrie shells came from a camel burial found under a large tumulus in Firka (Kirwan 1939, 3, object An1/5).

Two Marginella sp. shells were found in $\mathrm{T}_{7}$ : $\mathrm{Z}_{7} / 8.2$, $\mathrm{Z}_{7} / 9.2$ [see Fig. 4.1]. Their apices had been removed. Marginella sp. shells perforated in the same way were found in a late antique trash dump in Berenike (Then-Obłuska 2015b, Fig. 1:6) and in a post-Meroitic Ashkeit grave (ThenObłuska 2018, Pl. 2.4). Marginella sp. specimens known from Meroitic and early Roman bead assemblages tend to have their bodies removed (Then-Obłuska 2015a; 2015b).

\subsection{Ostrich Eggshell}

Ostrich eggshell was an easily available material and yet only 14 beads recorded from El-Zuma were made of it. Two general types were distinguished: large disc and small disc to short cylinder. The large discs were cut from pieces of ostrich eggshell perforated by pecking the centre from one or both ends. The edges were retouched. The surface around the lip of the perforation remained unworked. Large beads measure about $15 \mathrm{~mm}$ in diameter [Figs 4.2: $\mathrm{Z} 28 / 15.1, \mathrm{Z} 28 / 17.1,4.6,4.8]$, compared to the $4.5 \mathrm{~mm}$ diameter of the smaller type ( $\left.\mathrm{Z}_{5} / 29, \mathrm{Z}_{13} / 33, \mathrm{Z} 16 / 22, \mathrm{Z}_{24} / 49.1\right)$ [see Fig. 4.2].

\subsection{Coral}

A single coral bead Z25/35, not illustrated here, was recorded (for an earring with coral bead, see Chapter 5.1.5). Short-to-long cylinder beads made of Corallium sp. were common in late Roman/early Byzantine Egypt and postMeroitic Nubia (e.g. Then-Obłuska 2015b, Fig. 2.2; Emery and Kirwan 1938, Pls 43-44). In the Fourth Cataract region, salmon-coloured specimens were found in burial T1.81 at Musa (National Museum in Warsaw, Inv. No. 239056, Then-Obłuska 2018, Pl. 3) and in a grave at Tabo, where they formed part of a belt (Jacquet-Gordon and Bonnet 1971, 81).

\subsection{Stone}

More than 160 stone beads and pendants were recorded. Stone (quartz, agate, carnelian, black steatite, and what is most probably sandstone) beads were produced using one of two techniques: perforation from either one or both ends. Here and in Chapter 5.1.9, carnelian is defined as an orangey or reddish chalcedony with essentially no banding. All remaining varieties of chalcedony, with either banding or other patterns and of various colours, are referred to as agate.

1.4.1 Stone Beads and Pendants Drilled from One End Most of the beads were drilled from one end and they are characterized by truncated conical perforations. Some of them bear traces of saw marks across the larger hole. Saw marks made it easier to set the drill in place, and they are typical of Egyptian and Nubian stone perforating (ThenObłuska 2015a; 2015b). Among the small beads there are examples that are truncated and conical $\left(\mathrm{Z}_{4} / 49.1-\right.$ 4, $\mathrm{Z}_{4} / 175$, Z16/21), globular ( $\left.\mathrm{Z}_{4} / 5^{0.1}\right)$, long and ellipsoid $\left(\mathrm{Z}_{4} / 176, \mathrm{Z}_{4} / 178, \mathrm{Z} 16 / 2 \mathrm{Oa}, \mathrm{c}\right)$ and pear-shaped $\left(\mathrm{Z}_{4} / 48.1-2\right.$, Z16/2ob) [Fig. 4.3].

Small beads of black steatite, and white quartz, and red agate, are the most characteristic types in Early Makurian El-Zuma. They have already been identified in the Fourth Cataract region. They are also known from many Nobadian sites in Lower Nubia (Then-Obłuska 2016a; 2016c and references: Vila 1984, Fig. 219,92; Pellicer Catalán and Llongueras Campañà 1965, Fig. 41,114; Presedo Velo, Blanco y Caro, and Pellicer Catalán 1970, Fig. 215,158; Farid 1963, Fig. 58,11; Kirwan 1939, Pl. Xx:14), including the royal cemeteries of Qustul and Ballana (Emery and Kirwan 1938, Pl. 43, Types 53-54 =JE [ = Egyptian Museum, Cairo] 8o899, 

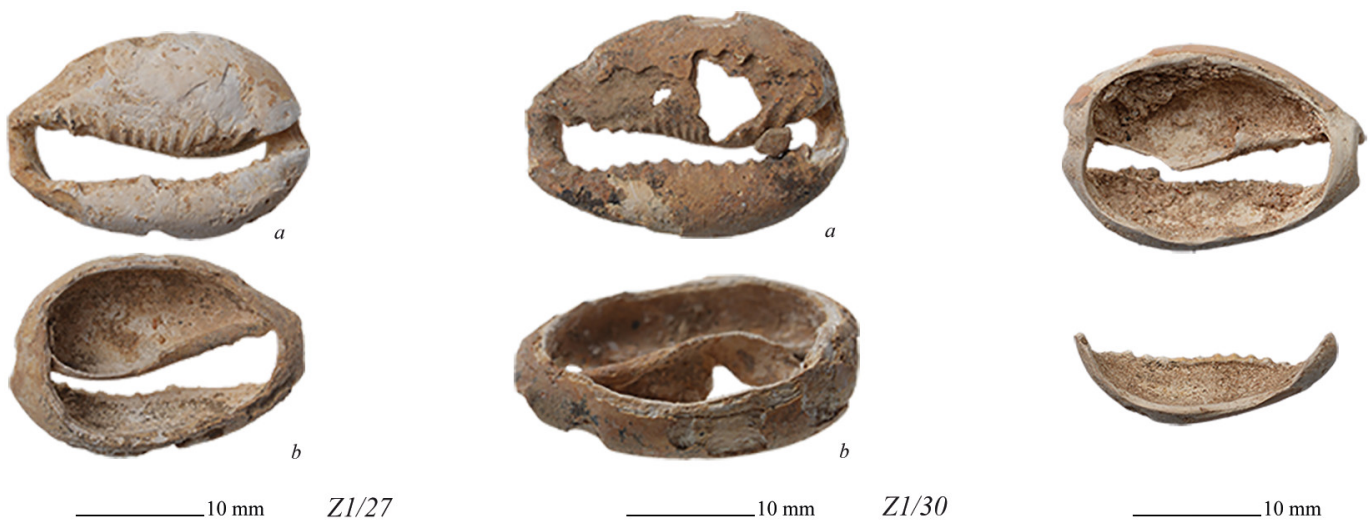

$1 / 27$
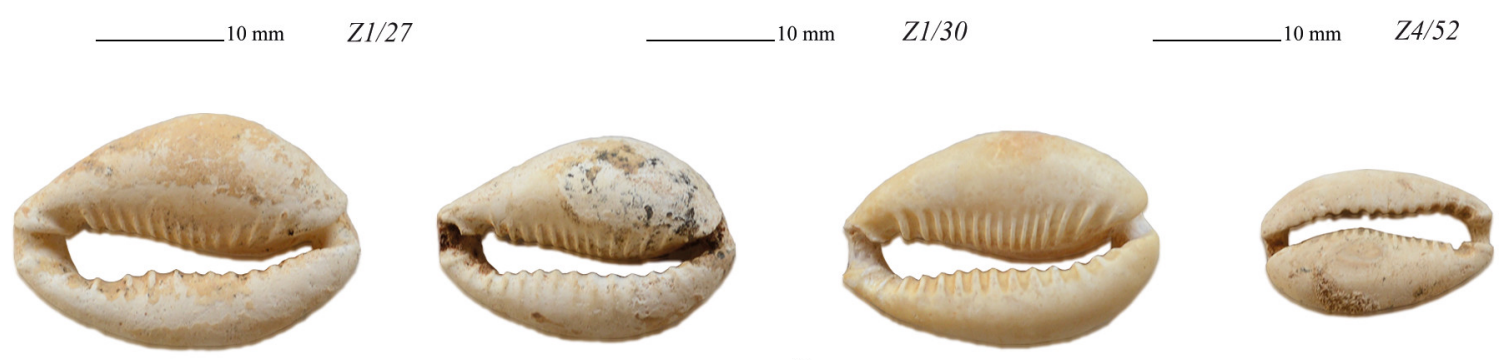

$10 \mathrm{~mm}$

Z7/8.1
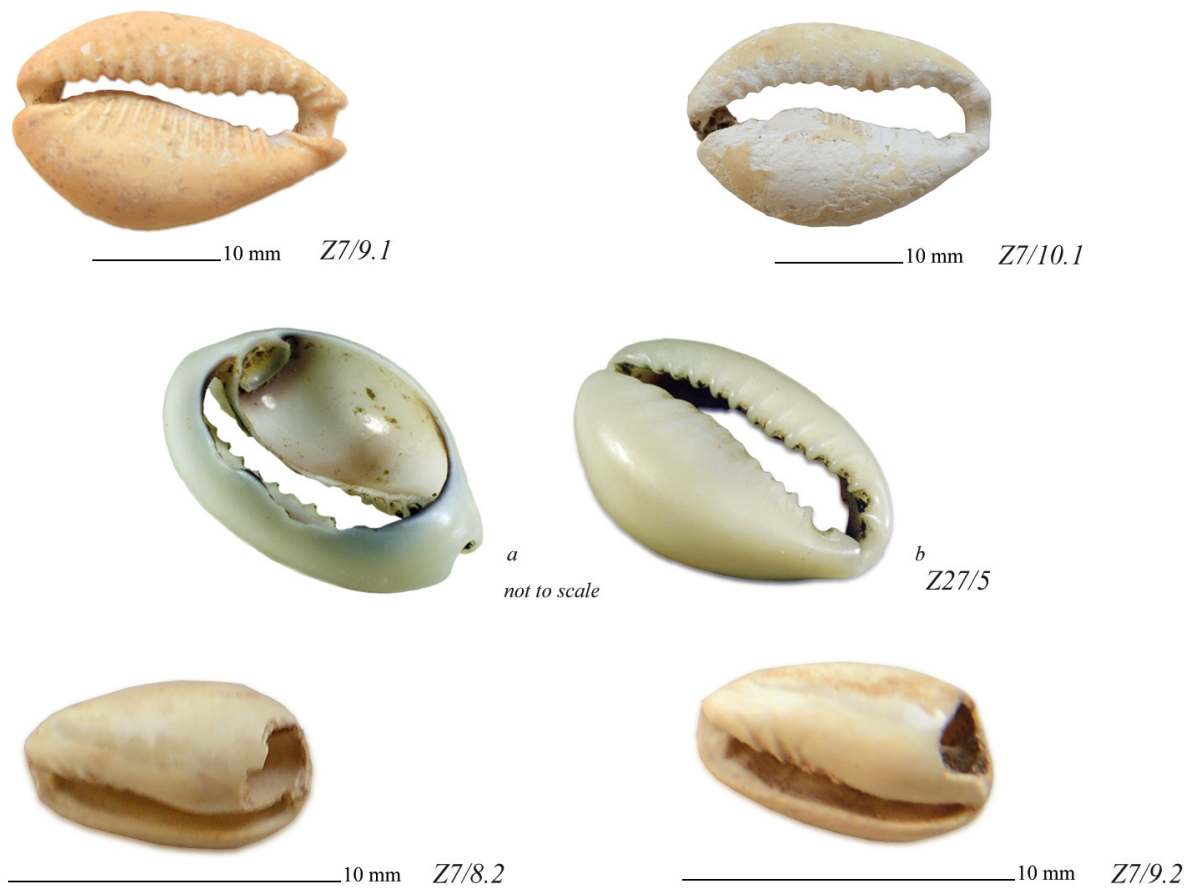

FIGURE 4.1 Marine mollusc shell beads PHOTOS BY A. KAMROWSKI, PLATE BY J. THEN-OB€USKA

70264, 70275, 7026o, personal observation). White, red, and black beads were found strung alternately at the latter site. Furthermore, truncated conical beads made of a variety of stones were found on the neck of a king buried in Tomb 8o at Ballana (Emery and Kirwan 1938, 211, Cat. No. 152, Pl. 46C =JE 70258).

Larger examples are characterized by a truncated conical perforation and a saw mark next to the larger hole. These are large globular beads of about $10 \mathrm{~mm}$ in diameter, made of red or white quartz (Z28/15), long barrels of white stone $\left(\mathrm{Z}_{17} / 7\right)$, and teardrop pendants with rounded bases $\left(Z_{17} / 6, Z_{17} / 9, Z_{20} / 12\right)$ [see Fig. 4.3]. These types are commonly recorded in Late Meroitic to transitional Late Meroitic/post-Meroitic graves in the Fourth Cataract region (Then-Obłuska 2014, Pl. II, Cat. 148, 150, 151, 175 spherical, 173 teardrop, 220, 225 long barrels; Longa 2011, Fig. 4 spherical beads and teardrop pendants) and up to the Sixth Cataract (Pokorná et al. 2014, spherical beads). 

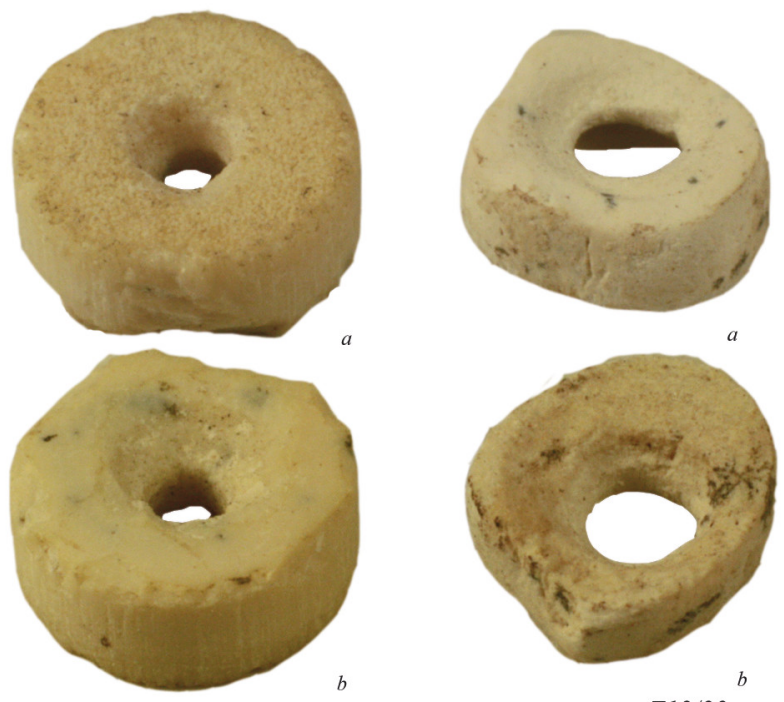

Z13/33
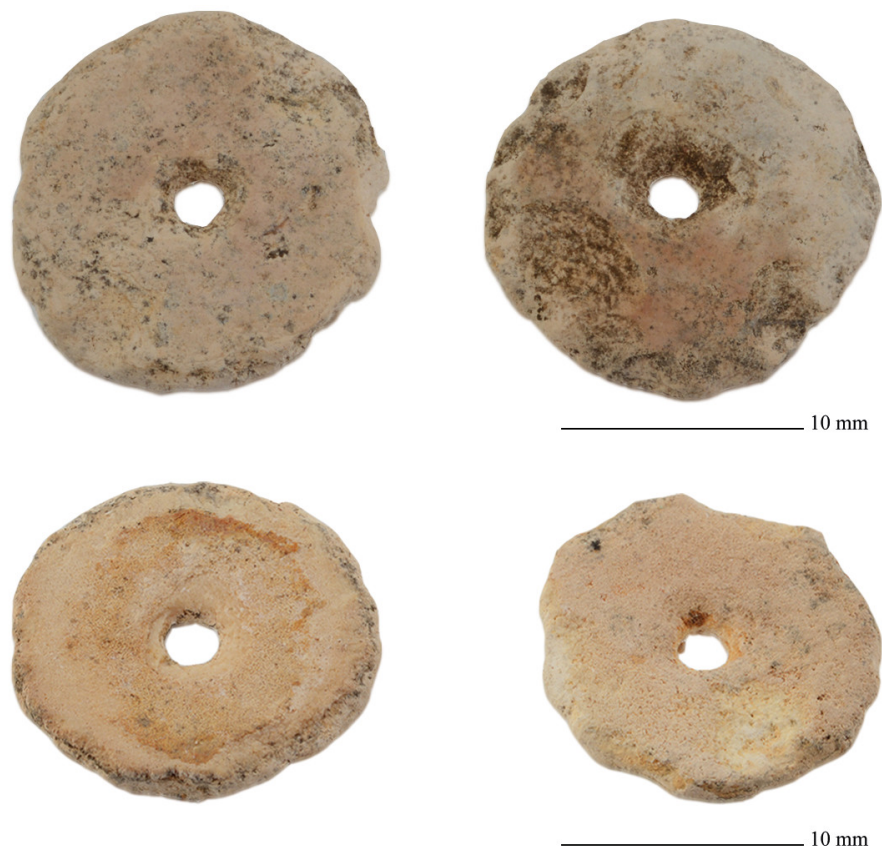
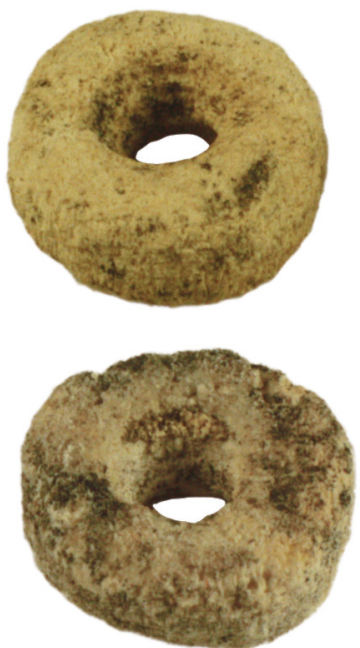

$Z 16 / 22$

not to scale

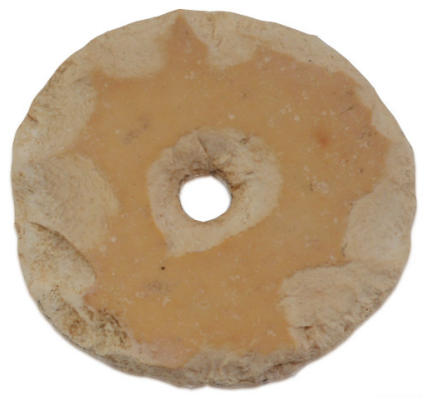

Z28/15.1

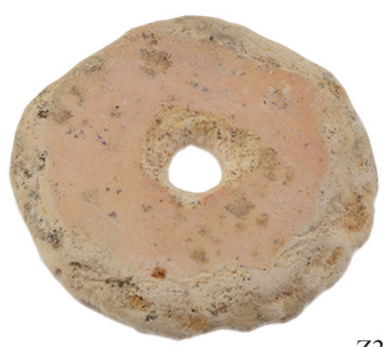

Z28/17.1

FIGURE 4.2 Ostrich-eggshell beads PHOTOS BY A. KAMROWSKI, PLATE BY J. THEN-OBŁUSKA

1.4.2 Stone Beads Drilled from Both Ends

Some beads were perforated from both ends, resulting in a double parallel perforation. Examples include four large transparent rock crystal beads $(\mathrm{Z} 4 / 48.3)$ [Fig. 4.4], along with similar ones discovered in 4 th- 7 th-century Kharga in the Western Desert, Egypt (M E T [= Metropolitan Museum of Art, New York] 25.10.20.96; 31.8.33, personal observation). In Nubia, beads of this kind were found only on the necks of kings from the Ballana burials: Tomb 80 (Emery and Kirwan 1938, 211, object B.80-130, Cat. 155 =JE 70283) and Tomb 95 (Emery and Kirwan 1938, 212, object B.9568, Cat. 157). The clarity and transparency of this material is said to have been especially valued in religious spheres as a symbol of purity (e.g. Dubin 2009, 77). A few rock crystal beads were discovered in an early Christian context in the Church of the Granite Columns in Dongola (ThenObłuska 2013, Fig. 3:1).

Two large lenticular beads of dark agate, $\mathrm{Z}_{7} / 10.2$ and $\mathrm{Z}_{7} / 16$, were recovered from a context associated with $\mathrm{T} .7$ [see Fig. 4.4]. They measure approximately $23 \mathrm{~mm}$ in diameter. A bead of this kind was found in a tomb at ElDetti, a cemetery contemporary with the site at El-Zuma (Then-Obłuska 2016a, Fig. 1 F, col. Fig. 3 F). Similar large lenticular beads were found on the left arm of a man buried in Ballana Tomb 9, dating from the 4th century AD; this man was apparently a warrior (Emery and Kirwan 1938, 


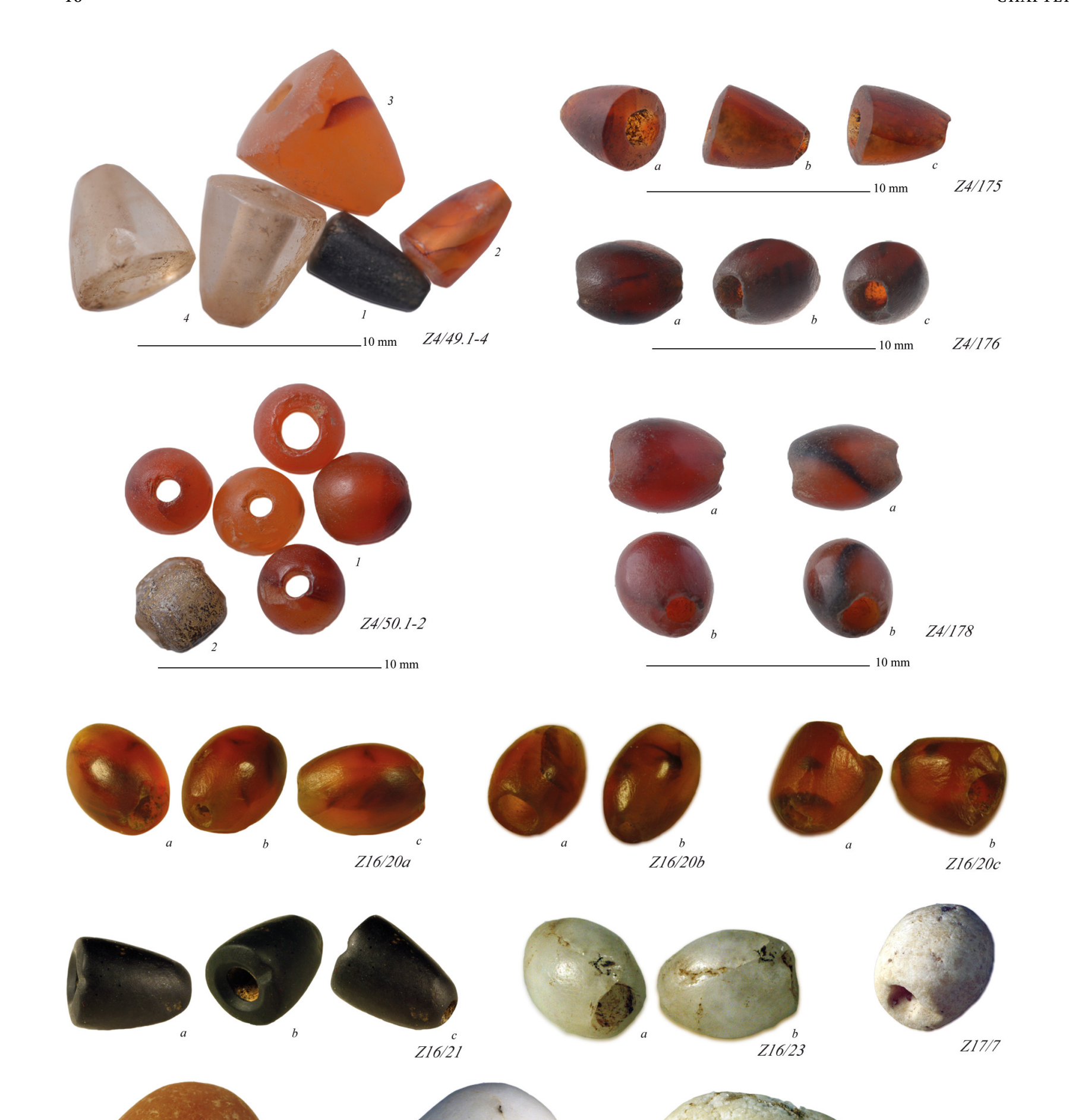



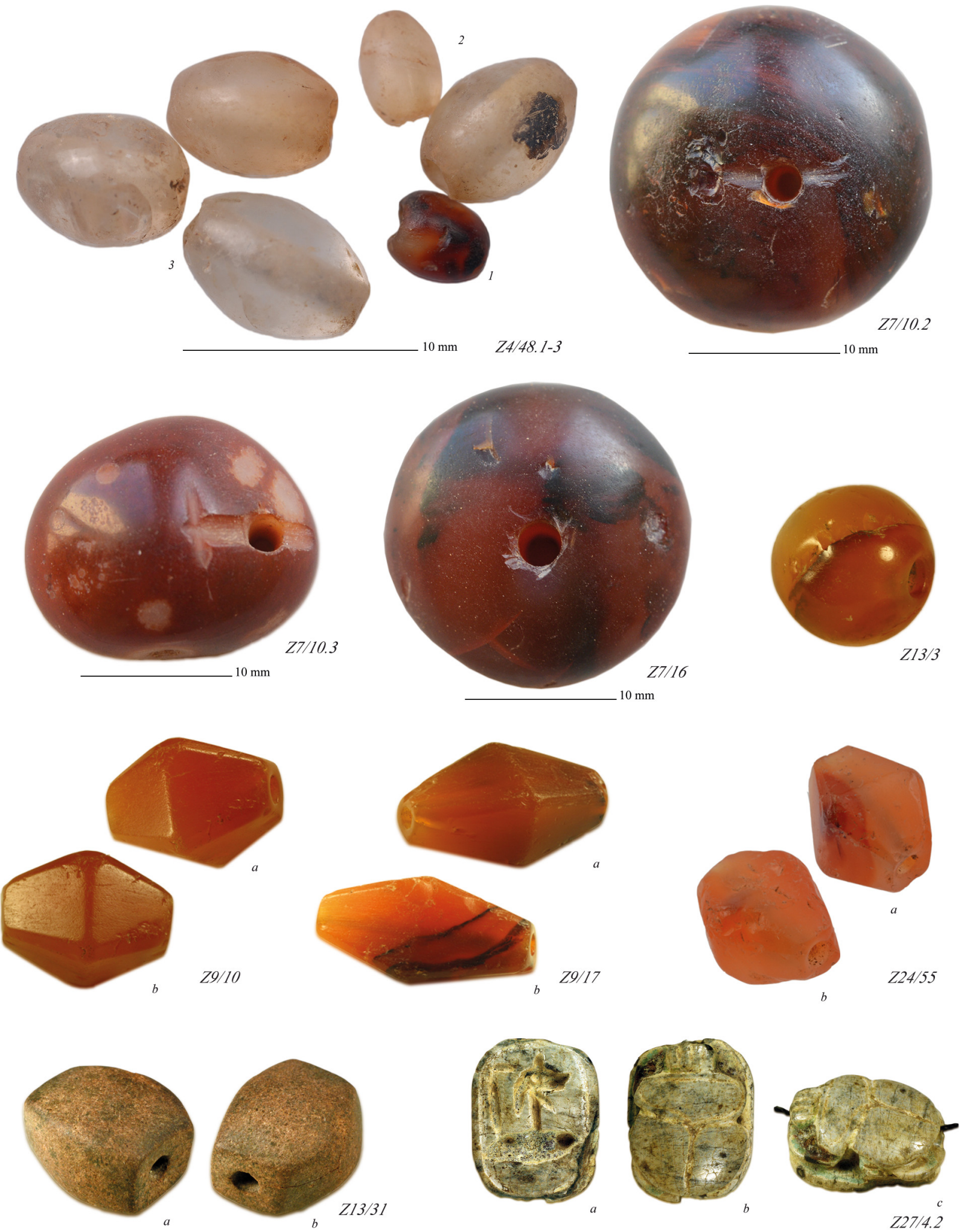

FIGURE 4.4 Stone beads perforated from both ends PHOTOS BY A. KAMROWSKI, PLATE BY J. THEN-OBŁUSKA 
Pl. 38B: B.9-3; Wenig 1978, 309, Cat. 309, personal observation). Tomb B.9 is dated to AD 430/440 (Török 1986, 197). However, another two bracelets were found on the right and left wrists of an adult queen in tomb B.47 (Emery and Kirwan 1938, Pl. 38A: B.47-26, 27), dated to AD 430. Similar beads are exhibited at the Sudan National Museum (SNM 3230); they were registered as coming from the Oxford Excavations at Firka. Indeed, the beads were found as a bracelet on the body marked as $\mathrm{E}$, that of an adult in Tomb A.11 at cemetery A (Kirwan 1939, 6, object A.11/62, Pl. Xx: Type $5 \mathrm{a}$, described as carnelian). The Firka site is considered to be of rather late date, that is, AD $490-570$ (Williams 1991, 12). Z7/10.3 is a perforated pebble pendant [see Fig. 4.4]. Saw marks are visible around the hole.

Long, square to rectangular, biconical carnelian beads Z9/10, Z9/17 and Z24/55 were drilled from both ends, and are characterized by a double parallel perforation [see Fig. 4.4]. They measure about $9 \mathrm{~mm}$ in thickness and from $12 \mathrm{~mm}$ to $20 \mathrm{~mm}$ in length. Examples have been recorded from early Byzantine Berenike, Egypt (see ThenObłuska 2015b, Fig. 3.6-7), Tell al-Sin and Deir el-Zor, Syria (Montero Fenollós and Al-Shbib 2008, Pl. LX:1), Lower Nubian Qustul, dated to AD 370/380-410 (OIM [= Oriental Institute Museum] E2O3o8, E2O624M, E21367-personal observation), Fourth Cataract sites dated to the transitional Late Meroitic/post-Meroitic period (Then-Obłuska 2014, Pl. II, Cat. 215, 216) and further up the Nile at Gabati (Edwards 1998, Fig. 10:74). Whether copper drills and abrasive or single- and double-diamond drills were used is not clear. The latter method would indicate their Asian origin (Kenoyer 2003).

The slightly reddish, rectangular truncated biconical bead $\mathrm{Z}_{13} / 31$, perforated from both ends, was most probably made of sandstone [see Fig. 4.4]. It measures $10 \mathrm{~mm}$ in width and $11 \mathrm{~mm}$ in length.

\subsection{Glazed Steatite}

The sole scarab bead Z27/4, carved in soapstone, features traces of green glaze in a few places [see Fig. 4.4]. It measures $10.2 \mathrm{~mm}$ in width and $13 \mathrm{~mm}$ in length.

\subsection{Faience}

Faience (also known as glazed composition) beads constitute the overwhelming majority of the assemblage. Almost two thousand faience beads were recorded.

Faience beads are characterized by the porosity of their quartzite bodies, which is probably attributable to the large share of natron used in faience production in the post-Meroitic period in the Fourth Cataract region (ThenObłuska 2014, 1070). Beads were produced by segmenting hand-folded long tubes into shorter and longer pieces. The fact that whitish parts are visible in the cores of broken beads suggests that they were glazed using the application technique. Blue glaze covers the outer surface of the body and the interior (perforation) surface, indicating they were dipped in liquid glaze. Because of the high core porosity, the glaze went deeply into the bodies and sometimes results in bluish bead sections. Due to their position during glazing, some beads are flattened on the side where they lack the glaze.

\subsubsection{Short and Standard Beads}

Short and standard beads measure from $3 \mathrm{~mm}$ to $6 \mathrm{~mm}$ in diameter and from $2 \mathrm{~mm}$ to $4 \mathrm{~mm}$ in length [see Figs 4.5, 4.6].

\subsubsection{Long Tubular Beads}

Long tubular examples Z22/9, Z28/4, Z28/15 and Z28/17 measure about $3.5^{-} 7 \mathrm{~mm}$ in diameter and up to $9 \mathrm{~mm}$ in length [see Fig. 4.6].

In general, faience beads are common finds at Lower Nubian and Fourth Cataract sites (e.g. Then-Obłuska 2014, Pl. 2; 2016a; Longa 2011, Fig. 4) and their distribution extends south to the Sixth Cataract region (Pokorná et al. 2014), to Botri south of Khartoum (Bashir 2007, Pl. 5), and to the west of the White Nile in Al-Khiday (Maritan et al. 2014, Fig. 3).

\subsection{Glass and Metal-in-Glass}

Almost one hundred glass beads and pendants were recorded. Glass beads were made of drawn or wound glass. One pendant was made of rod-pierced glass.

1.7.1 Drawn and Segmented Glass and Metal-in-Glass Many monochrome beads were made from drawn glass tubes. Such tubes could be segmented on grooved moulds or with a tool that resulted in the beads having constricted ends. They often appear covered with yellowish patina. The smaller specimens measure about $3 \cdot 3-5 \mathrm{~mm}$ in diameter and $2-3.5 \mathrm{~mm}$ in length. At El-Zuma they are represented by opaque red glass $\left(\mathrm{Z}_{17} / 10, \mathrm{Z}_{27} / 9\right)$ and dark blue beads (Z28/15.6) [see Fig. 4.8].

Two beads $\left(\mathrm{Z}_{4} / 5^{0.2}, \mathrm{Z}_{4} / 174\right)$ appear to be segments of a tube made of two layers of glass with silver foil inbetween [see Fig. 4.3: $\mathrm{Z}_{4} / 5 \mathrm{O} .2$ ]. Segmenting glass tubes in open moulds is a well-recognized Egyptian technique used in the manufacture of glass and metal-in-glass beads. Silver-in-glass specimens are one of the most characteristic features of post-Meroitic assemblages in Lower and Upper Nubia (e.g. Then-Obłuska 2014; 2018). 

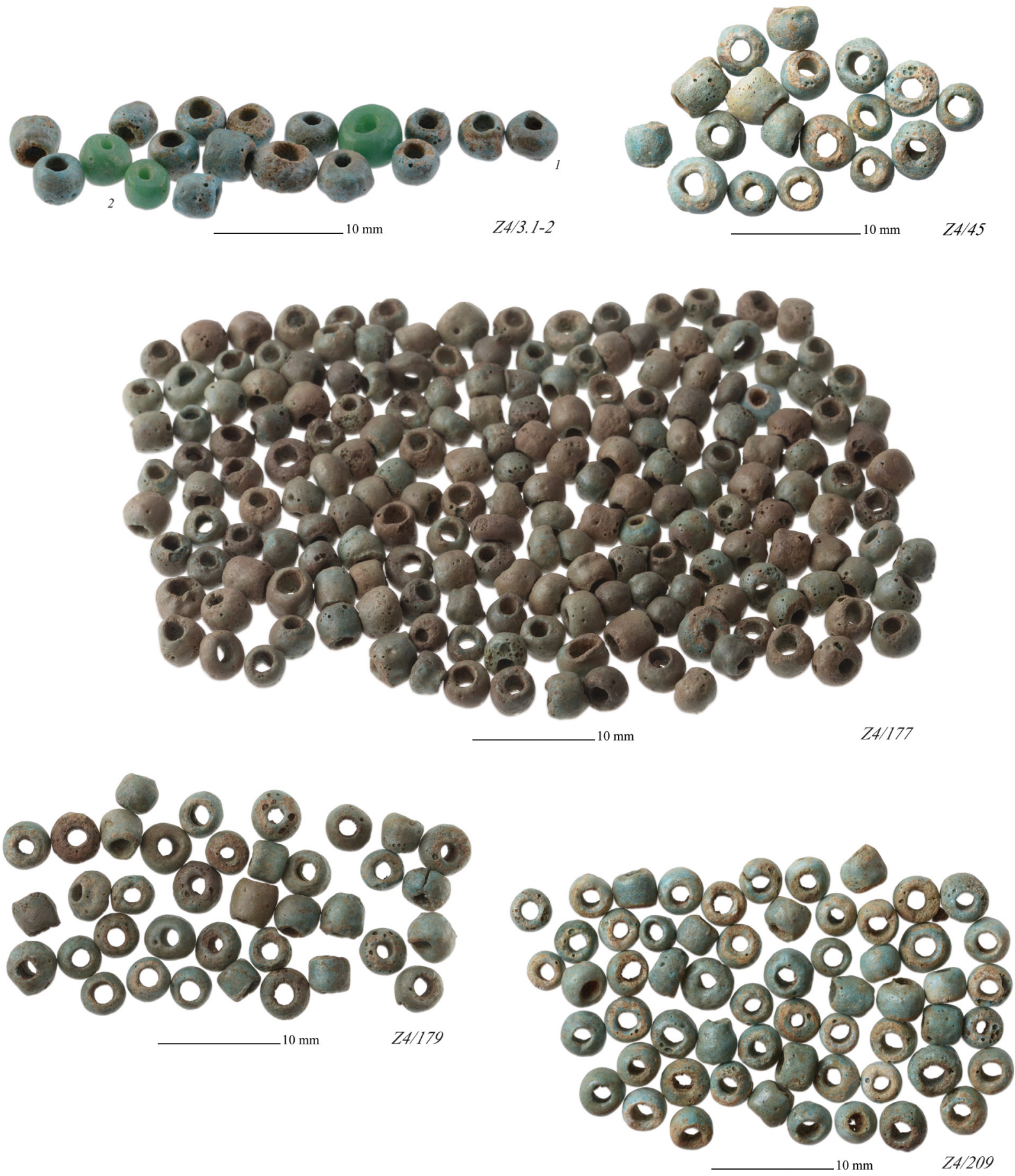

FIGURE 4.5 Faience and some glass beads

PHOTOS BY A. KAMROWSKI, PLATE BY J. THEN-OBŁUSKA

\subsubsection{Drawn and Rounded Glass}

Drawn glass tubes were cut up and the pieces were roughly rounded. Fifty-one are made of green $\left(\mathrm{Z}_{4} / 3, \mathrm{Z}_{4} / 5_{1}, \mathrm{Z}_{12} / 82\right.$, Z24/49, Z28/4, Z28/15) [see Fig. 4.5: Z4/3.2], two of orange $\left(\mathrm{Z}_{4} / 5_{1.1}\right)$, and two of orange-on-red glass $\left(\mathrm{Z}_{4} / 5^{1.2}\right)$, two of yellow (Z9/9, Z24/49.4), one of blue (Z24/49.3), and one of blue-green glass $\left(\mathrm{Z}_{2} 8 / 15.5\right)$ [see Figs $4 \cdot 7,4.8$ ]. Altogether, 59 beads of this type have been recorded at El-Zuma. They make up $63.4 \%$ of all glass beads and $2.6 \%$ of all beads found at this site.

Drawn and rounded beads have been discovered in many private and royal Nobadian and Early Makurian cemeteries in Lower and Upper Nubia (Then-Obłuska 2018; Then-Obłuska and Wagner 2019). Small monochrome beads with rounded ends come from the late antique Red Sea port sites of Berenike and Marsa Nakari 

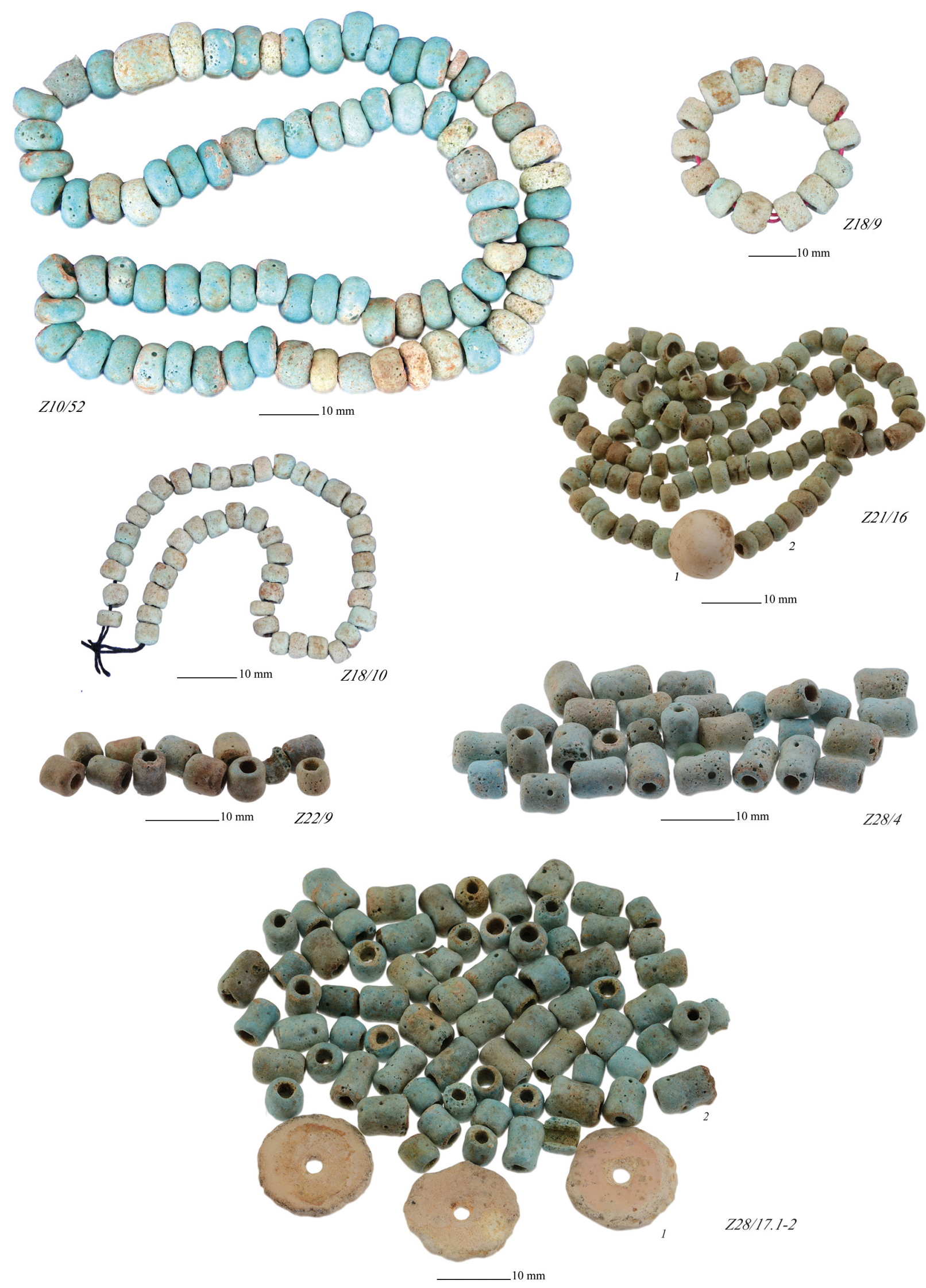

FIGURE 4.6 Faience and some stone and ostrich-eggshell beads

PHOTOS BY A. KAMROWSKI, PLATE BY J. THEN-OBEUSKA 

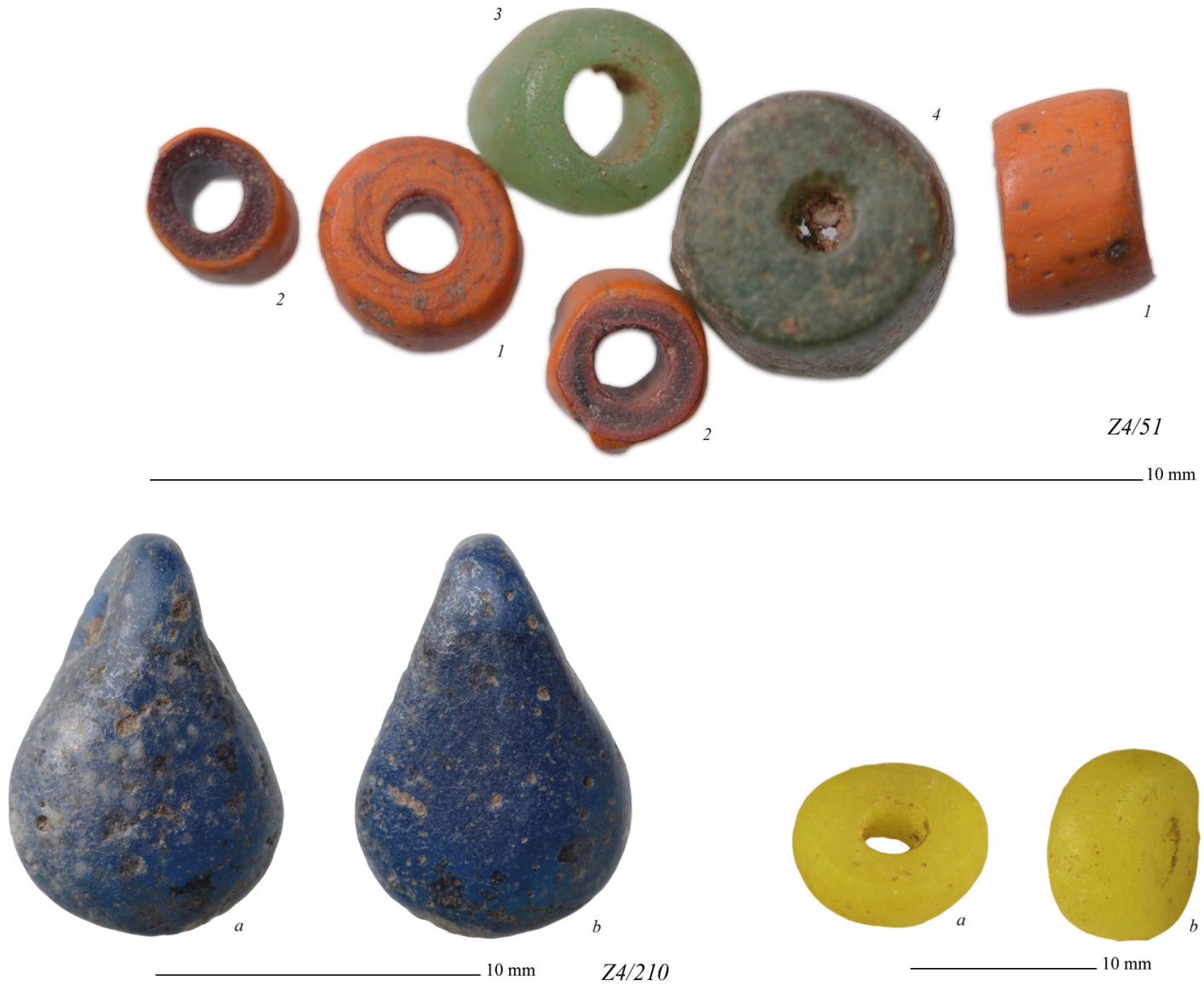

$Z 9 / 9$
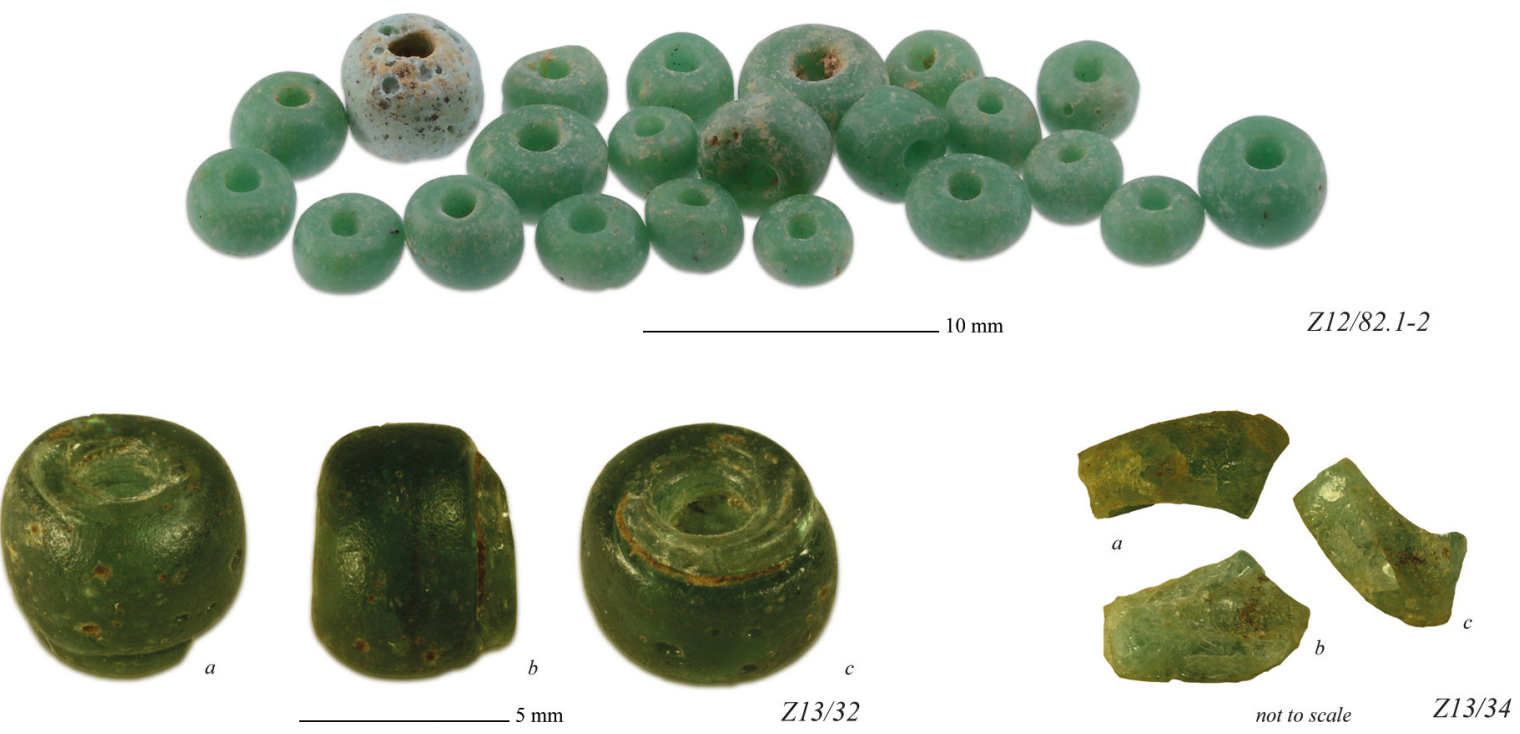

FIGURE 4.7 Glass beads

PHOTOS BY A. KAMROWSKI, PLATE BY J. THEN-OBŁUSKA 

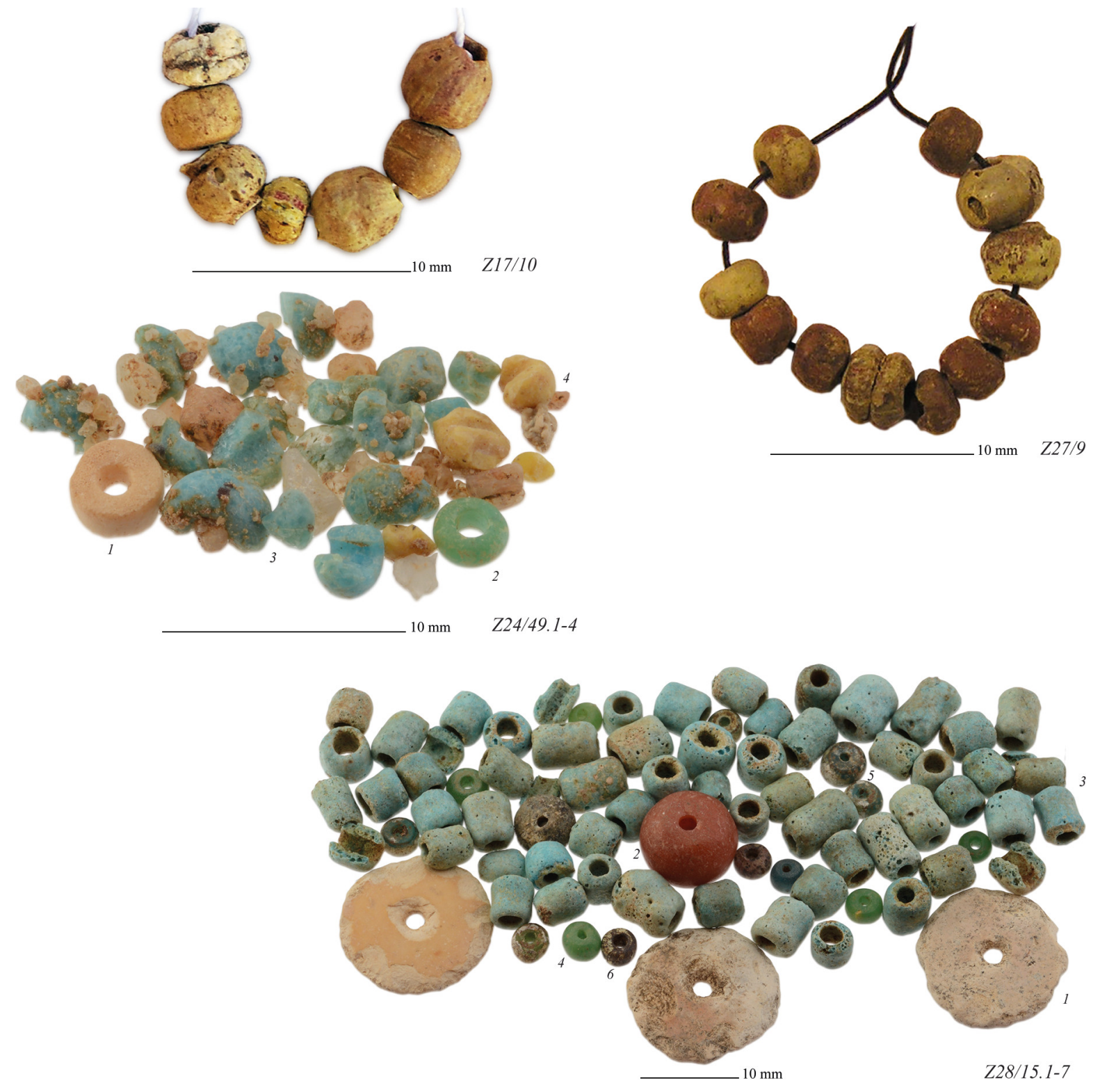

FIGURE 4.8 Glass and some ostrich-eggshell, stone and faience beads PHOTOS BY A. KAMROWSKI, PLATE BY J. THEN-OBŁUSKA

(e.g. Then-Obłuska 2015b, Fig. 4:33-41; 2019). Those in the form of an opaque orange layer above a translucent red one are rare. Ten such beads were identified from the Serra East 25 site and four from Nag el-Arab. Another two beads were recorded in Berenike (BE95-OO5-O13\#72, BE95o०5-TS\#97). In general, drawn and rounded beads are well known from South Asian, Indian, and Sri Lankan sites, where they were most probably produced (Dussubieux 2001, 105; Hannibal-Deraniyagala 2013, Note 13). Chemical composition analyses of beads from early Roman Quseir/Myos Hormos in Egypt and from Lower Nubian sites have confirmed their South Indian/Sri Lankan origin (Then-Obłuska and Dussubieux 2016; Then-Obłuska and Wagner 2017).

\subsubsection{Wound Glass}

An outstanding bead of wound glass in translucent green was also found at El-Zuma (Z13/32) [see Fig. 4.7].

\subsubsection{Rod-Pierced Glass}

Large flattened teardrop $\mathrm{Z}_{4} / 210$ was perforated by rodpiercing the dark blue glass in its upper part [see Fig. 4.7]. A similar example comes from a Coptic burial at Matmar (UC59788, tomb 1101). While blue and blue-green glass teardrop pendants characterize Nobadian assemblages in Lower Nubia (Then-Obłuska 2018), they have so far not been identified in Upper Nubia. 
Fourteen glass bead samples from the El-Zuma assemblage were selected for laboratory analysis, which was carried out in the Biological and Chemical Research Centre of the University of Warsaw, Poland. The aim was to evaluate the elemental composition of the glass beads by means of a sensitive instrumental method (LA-ICP-MS) (ThenObłuska and Wagner 2019).

In general, glass beads were manufactured using a sodarich flux mixed with different types of sand. Three main glass compositional groups were identified based on the content of $\mathrm{MgO}$ and $\mathrm{Al}_{2} \mathrm{O}_{3}$ : low-alumina soda-lime glass, high-alumina glass, and plant-ash soda-lime glass.

The results confirmed the presence of East Mediterranean and South Asian glass beads in the El-Zuma assemblage. While drawn and rounded glass beads were made of South Indian/Sri Lankan high-alumina glass, confirming macroscopic identification (compare section 4.1.7), the remaining analysed samples were made of Egyptian glass (Then-Obłuska and Wagner 2019).

\section{Catalogue [Table 4.1]}

The catalogue, in tabular form, presents beads and pendants according to find number. Object descriptions list (in sequence): figure number, find number (tumulus and object number), object type (B-bead, $\mathrm{P}$ - pendant), material, quantity, shape (according to Beck's 1928 nomenclature), technique of manufacture/production, colour and diaphaneity (o-opaque, st-semi-translucent, $\mathrm{t}-$ translucent, transparent), measurements (given in millimetres: D—diameter, L-length, W—width, Th.—thickness, $\mathrm{H}$-height, HD-hole diameter), find context, excavation season, references. The scale is $10 \mathrm{~mm}$, unless otherwise stated. 
TABLE 4.1 Catalogue of the beads and pendants

\begin{tabular}{|c|c|c|c|c|c|c|c|c|}
\hline $\begin{array}{l}\text { Figure } \\
\text { no. }\end{array}$ & $\begin{array}{l}\text { Tumulus } \\
\text { no. }\end{array}$ & Find no. & $\mathbf{B} / \mathbf{P}$ & Material & Quantity & Shape & Technique & $\begin{array}{l}\text { Colour(s) and dia- } \\
\text { phaneity }\end{array}$ \\
\hline 4.1 & T.1 & $\mathrm{Z} 1 / 27$ & $\mathrm{~B}$ & Mollusc shell; Cypraea annulus sp. & 1 & & & \\
\hline \multirow[t]{3}{*}{4.1} & T.1 & $\mathrm{Z1} / 30$ & $\mathrm{~B}$ & Mollusc shell; Cypraea annulus sp. & 1 & & & \\
\hline & $\mathrm{T} .3$ & $\mathrm{Z}_{3} / 8$ & $\mathrm{~B}$ & Faience & 1 & & & \\
\hline & T.3 & $\mathrm{Z}_{3} / 9$ & $\mathrm{~B}$ & Mollusc shell; accidental perforation & 1 & & & \\
\hline $4 \cdot 5$ & T.4 & $\mathrm{Z}_{4} / 3.1$ & $\mathrm{~B}$ & Faience & 15 & & & \\
\hline \multirow[t]{3}{*}{$4 \cdot 5$} & T.4 & $\mathrm{Z}_{4} / 3 \cdot 2$ & $\mathrm{~B}$ & Glass & 3 & & drawn & green \\
\hline & T.4 & $\mathrm{Z}_{4} / 3 \cdot 3$ & $\mathrm{~B}$ & Faience & 1 & globular & & \\
\hline & T.4 & $\mathrm{Z}_{4} / 3 \cdot 4$ & & Glass & 19 & & drawn & green \\
\hline \multirow[t]{3}{*}{$4 \cdot 5$} & T. 4 & $\mathrm{Z}_{4} / 45$ & B & Faience & 18 & & & \\
\hline & T.4 & $\mathrm{Z}_{4} / 46$ & B & Faience & 8 & & & \\
\hline & $\mathrm{T} .4$ & $\mathrm{Z}_{4} / 47$ & B & Faience & 222 & & & \\
\hline $4 \cdot 4$ & T.4 & $\mathrm{Z}_{4} / 48.1$ & B & Agate & 1 & ellipsoid & & red \\
\hline 4.4 & $\mathrm{~T} .4$ & $\mathrm{Z}_{4} / 48.2$ & $\mathrm{~B}$ & Rock crystal & 1 & ellipsoid & & \\
\hline 4.4 & $\mathrm{~T} .4$ & $\mathrm{Z}_{4} / 48.3$ & $\mathrm{~B}$ & Rock crystal & 4 & ellipsoid & & \\
\hline $4 \cdot 3$ & T. 4 & $\mathrm{Z}_{4} / 49.1$ & B & Stone & & truncated conical & & black \\
\hline $4 \cdot 3$ & T. 4 & $\mathrm{Z}_{4} / 49.2$ & B & Agate & & truncated conical & & red \\
\hline $4 \cdot 3$ & $\mathrm{~T} .4$ & $\mathrm{Z}_{4} / 49 \cdot 3$ & $\mathrm{~B}$ & Agate & & truncated conical & & red \\
\hline $4 \cdot 3$ & T.4 & $\mathrm{Z}_{4} / 49 \cdot 4$ & $\mathrm{~B}$ & Rock crystal & & truncated conical & & \\
\hline $4 \cdot 3$ & T. 4 & $\mathrm{Z}_{4} / 5^{0.1}$ & B & Stone & 5 & & & red \\
\hline $4 \cdot 3$ & $\mathrm{~T} .4$ & $\mathrm{Z}_{4} / 5^{0.2}$ & B & Metal-in-glass & 1 & & & \\
\hline $4 \cdot 7$ & T.4 & $\mathrm{Z}_{4} / 51.1$ & $\mathrm{~B}$ & Glass & 2 & & drawn and rounded & orange \\
\hline $4 \cdot 7$ & T. 4 & $\mathrm{Z}_{4} / 5^{1.2}$ & B & Glass & 2 & & drawn and rounded & orange-on-red \\
\hline $4 \cdot 7$ & T. 4 & $\mathrm{Z}_{4} / 51 \cdot 3$ & B & Glass & 1 & & drawn and rounded & green \\
\hline $4 \cdot 7$ & T.4 & $\mathrm{Z}_{4} / 51.4$ & $\mathrm{~B}$ & Glass & 1 & short cylinder & & green \\
\hline \multirow[t]{3}{*}{4.1} & T.4 & $\mathrm{Z}_{4} / 5^{2}$ & B & Mollusc shell; Cypraea annulus sp. & 2 & $\begin{array}{l}1 \text { shell and } 1 \text { frag- } \\
\text { ment }\end{array}$ & & \\
\hline & T.4 & $\mathrm{Z}_{4} / 137$ & B & Faience & 35 & & & \\
\hline & $\mathrm{T} .4$ & $\mathrm{Z}_{4} / 174$ & B & Metal-in-glass & 1 & & & \\
\hline $4 \cdot 3$ & T.4 & $\mathrm{Z}_{4} / 175$ & B & Agate & 1 & conical & & red \\
\hline $4 \cdot 3$ & T.4 & $\mathrm{Z}_{4} / 176$ & B & Agate & 1 & ellipsoidal & & dark red \\
\hline $4 \cdot 5$ & T.4 & $\mathrm{Z}_{4} / 177$ & $\mathrm{~B}$ & Faience & 191 & & & \\
\hline $4 \cdot 3$ & T. 4 & $\mathrm{Z}_{4} / 178$ & B & Agate & 2 & ellipsoidal & & red \\
\hline $4 \cdot 5$ & T.4 & $\mathrm{Z}_{4} / 179$ & B & Faience & 37 & & & \\
\hline 4.5 & T.4 & $\mathrm{Z}_{4} / 209$ & $\mathrm{~B}$ & Faience & $5^{8}$ & & & \\
\hline \multirow[t]{6}{*}{$4 \cdot 7$} & T. 4 & $\mathrm{Z}_{4} / 210$ & $\mathrm{P}$ & Glass & 1 & teardrop pendant & rod-pierced & blue \\
\hline & $\mathrm{T} .5$ & $\mathrm{Z}_{5} / 7$ & $\mathrm{~B}$ & Glass & 1 & & & \\
\hline & $\mathrm{T} .5$ & $\mathrm{Z}_{5} / 8$ & $\mathrm{~B}$ & Faience & 12 & & & \\
\hline & $\mathrm{T} .5$ & $\mathrm{Z}_{5} / 13$ & $\mathrm{~B}$ & Faience & 1 & & & \\
\hline & $\mathrm{T} .5$ & $Z_{5} / 29$ & B & Ostrich eggshell & 1 & & & \\
\hline & $\mathrm{T} .7$ & $\mathrm{Z}_{7} / 1$ & $\mathrm{~B}$ & Mollusc shell; Cypraea annulus sp. & 1 & & & \\
\hline 4.1 & $\mathrm{~T} .7$ & $\mathrm{Z}_{7} / 8.1$ & B & Mollusc shell; Cypraea annulus sp. & 4 & & & \\
\hline \multirow[t]{2}{*}{4.1} & T.7 & $\mathrm{Z}_{7} / 8.2$ & $\mathrm{~B}$ & Mollusc shell; Marginella sp. & 1 & & & \\
\hline & T.7 & $\mathrm{Z}_{7} / 8.3$ & $\mathrm{~B}$ & Faience & 10 & & & \\
\hline 4.1 & $\mathrm{~T} .7$ & $\mathrm{Z}_{7} / 9.1$ & B & Mollusc shell; Cypraea annulus sp. & 1 & & & \\
\hline 4.1 & T.7 & $\mathrm{Z}_{7} / 9.2$ & B & Mollusc shell; Marginella sp. & 1 & & & \\
\hline 4.1 & T.7 & $\mathrm{Z}_{7} / 10.1$ & $\mathrm{~B}$ & Mollusc shell; Cypraea annulus sp. & 1 & & & \\
\hline 4.4 & $\mathrm{~T} .7$ & $\mathrm{Z}_{7} / 10.2$ & $\mathrm{~B}$ & Stone, agate & 1 & lenticular & & red \\
\hline 4.4 & $\mathrm{~T} .7$ & $\mathrm{Z}_{7} / 10.3$ & $\mathrm{~B}$ & Stone & 1 & pebble pendant & & red \\
\hline \multirow[t]{4}{*}{4.4} & $\mathrm{~T} .7$ & $\mathrm{Z}_{7} / 16$ & B & Stone & & lenticular? & & \\
\hline & Т.7 & $\begin{array}{l}\mathrm{Z}_{7 / 79} \\
\text { ( } \mathrm{Z}_{7 / 1} \text {-old } \\
\text { number) }\end{array}$ & $\mathrm{B}$ & Mollusc shell; Cypraea annulus sp. & 1 & pendant & & white (o) \\
\hline & T.8 & $\mathrm{Z} 8 / 10$ & $\mathrm{~B}$ & Faience & 1 & barrel & & blue \\
\hline & Т.9 & $\mathrm{Zg} / 8$ & B & Faience & $\begin{array}{l}25 \text { (and a few } \\
\text { fragments) }\end{array}$ & oblate & & light green $(\mathrm{o})$ \\
\hline
\end{tabular}


D $\mathrm{L} / \mathrm{Th} / \mathrm{W}$
HD

Context data
Season

References
Top of tunnel fill (NW part, near entrance to chamber)

W part of chamber 1

Robber pit

Tunnel

Tunnel

Tunnel

Tunnel

Tunnel

Shaft and tunnel secondary deposit (2013 excavation)

$\mathrm{W}$ tunnel, fill, $\mathrm{W}$ part of $\mathrm{E}$ side of entrance

W tunnel, fill, $2.4 \mathrm{O}-4.25 \mathrm{~m}$ from edge of shaft, layer 5

$\mathrm{W}$ tunnel, fill, $2.40-4.25 \mathrm{~m}$ from edge of shaft, layer 5

$\mathrm{W}$ tunnel, fill, $2.40-4.25 \mathrm{~m}$ from edge of shaft, layer 5

$\mathrm{W}$ tunnel, fill, $2.40-4.25 \mathrm{~m}$ from edge of shaft, layer 5

W tunnel, fill, 2.40-4.25 $\mathrm{m}$ from edge of shaft, layer 5

W tunnel, fill, $2.40-4.25 \mathrm{~m}$ from edge of shaft, layer 5

$\mathrm{W}$ tunnel, fill, $2.40-4.25 \mathrm{~m}$ from edge of shaft, layer 5

$\mathrm{W}$ tunnel, fill, $2.40-4.25 \mathrm{~m}$ from edge of shaft, layer 5

W tunnel, fill, 2.40-4.25 $\mathrm{m}$ from edge of shaft, layer 5

W tunnel, fill, $2.40-4.25 \mathrm{~m}$ from edge of shaft, layer 5

$\mathrm{W}$ tunnel, fill, $2.40-4.25 \mathrm{~m}$ from edge of shaft, layer 5

$\mathrm{W}$ tunnel, fill, $2.40-4.25 \mathrm{~m}$ from edge of shaft, layer 5

$\mathrm{W}$ tunnel, fill, $2.40-4.25 \mathrm{~m}$ from edge of shaft, layer 5

$\mathrm{W}$ tunnel, fill, $2.40-4.25 \mathrm{~m}$ from edge of shaft, layer 5

W tunnel, fill, $2.40-4.25 \mathrm{~m}$ from edge of shaft, layer 5

W tunnel, fill, 9.oo $\mathrm{m}$ from edge of shaft, dark bottom layer

W tunnel, fill, entrance to W room (W chamber?)

W tunnel, fill, entrance to W room (W chamber?)

W tunnel, fill, entrance to W room (W chamber?)

$\mathrm{W}$ tunnel, fill, entrance to W room (W chamber?)

W tunnel, fill, entrance to W room (W chamber?)

W tunnel, fill, entrance to W room (W chamber?)

E tunnel, S part, dark layer

E tunnel, S part, dark layer

Chamber 1

Chamber 1, by brick blocking wall at central part

Shaft fill, by SE corner

Tunnel fill

$17.55 \times 25.61 \times 6.58 \quad 18.5 \times 14.64$

Found close to first pillar

Found close to first pillar

Found close to first pillar

In tunnel entrance

In tunnel entrance
2017

2017

2014

2014

2013

2013

2013

2013

2017

2017

2017

2017

2017

2017

2017

2017

2017

2017

2017

2017

2017

2017

2017

2017

2017

2017

2017

2017

2017

2017

2017

2017

2017

2017

2007

2007

2007

2007

2011

2015

2015

2015

2015

2015

2015

2015

2015

2015

2011

$17.55 \times 25.61 \times$

6.58

4.27
$18.5 \times 14.64 \quad$ Tunnel fill

Burial chamber, E part

Shaft, S part, near damaged blocking wall (chamber 1 )
Then-Obłuska 2017, Fig. 1

Then-Obłuska 2017, Fig. 1

Then-Obłuska 2016c, Fig. 5

Then-Obłuska 2016c, Fig. 5

Then-Obłuska 2017, Fig. 2 Then-Obłuska 2017, Fig. 2 Then-Obłuska 2017, Fig. 2 Then-Obłuska 2017, Fig. 2 Then-Obłuska 2017, Fig. 2 Then-Obłuska 2017, Fig. 2 Then-Obłuska 2017, Fig. 2 Then-Obłuska 2017, Fig. 2 Then-Obłuska 2017, Fig. 2 Then-Obłuska 2017, Fig. 3 Then-Obłuska 2017, Fig. 3 Then-Obłuska 2017, Fig. 3 Then-Obłuska 2017, Fig. 3 Then-Obłuska 2017, Fig. 1

Then-Obłuska 2017, Fig. 2 Then-Obłuska 2017, Fig. 2

Then-Obłuska 2017, Fig. 2

Then-Obłuska 2017, Fig. 3 Then-Obłuska 2017, Fig. 3

Then-Obłuska 2017, Fig. 1 Then-Obłuska 2017, Fig. 1

Then-Obłuska 2017, Fig. 1 Then-Obłuska 2017, Fig. 1 Then-Obłuska 2017, Fig. 2 Then-Obłuska 2017, Fig. 2 Then-Obłuska 2017, Fig. 2 
TABLE 4.1 Catalogue of the beads and pendants (cont.)

\begin{tabular}{|c|c|c|c|c|c|c|c|c|}
\hline $\begin{array}{l}\text { Figure } \\
\text { no. }\end{array}$ & $\begin{array}{l}\text { Tumulus } \\
\text { no. }\end{array}$ & Find no. & $\mathbf{B} / \mathbf{P}$ & Material & Quantity & Shape & Technique & $\begin{array}{l}\text { Colour(s) and dia- } \\
\text { phaneity }\end{array}$ \\
\hline $4 \cdot 7$ & Т.9 & $\mathrm{Z} 9 / 9$ & B & Glass & 1 & short cylinder & drawn & light yellow (o) \\
\hline \multirow[t]{5}{*}{$4 \cdot 4$} & T.9 & $\mathrm{Z} 9 / 10$ & B & Stone; carnelian & 1 & long square bicone & & $\operatorname{red}(\mathrm{st})$ \\
\hline & Т.9 & $\mathrm{Z}_{9 / 13}$ & $\mathrm{~B}$ & Faience & 48 & barrel & & light green $(\mathrm{o})$ \\
\hline & T.9 & $\mathrm{Z9} / 14$ & $\mathrm{~B}$ & Faience & 1 & tubular, long & & light green $(\mathrm{o})$ \\
\hline & Т.9 & $\mathrm{Z9} / 15$ & B & Quartz & 2 & barrel standard & $\begin{array}{l}\text { polished; conical per- } \\
\text { foration }\end{array}$ & white (o) \\
\hline & T.9 & $\mathrm{Z9} / 16$ & B & Quartz & 1 & pear-shaped & polished & white (o) \\
\hline \multirow[t]{3}{*}{$4 \cdot 4$} & Т.9 & $\mathrm{Z9} / 17$ & $\mathrm{~B}$ & Stone; carnelian & 1 & long square bicone & & light to dark red (st) \\
\hline & T.10 & $\mathrm{Z10} / 5 \mathrm{O}$ & B & Stone? & 1 & pear-shaped & & black \\
\hline & T.10 & $\mathrm{Z} 1 \mathrm{o} / 5^{1}$ & B & Quartz & 1 & globular & $\begin{array}{l}\text { saw marks across lar- } \\
\text { ger hole }\end{array}$ & red \\
\hline \multirow[t]{5}{*}{4.6} & T.10 & $\mathrm{Z} 10 / 5^{2}$ & B & Faience & 80 & short oblate & & light blue \\
\hline & T.11 & $\mathrm{Z} 11 / 31.1$ & B & Faience & 10 (1 broken $)$ & $\begin{array}{l}\text { standard and long } \\
\text { tubular }\end{array}$ & glazed & $\begin{array}{l}\text { light blue; green/ } \\
\text { whitish cores }\end{array}$ \\
\hline & T.11 & $\mathrm{Z} 11 / 31.2$ & B & Faience & 7 & short tubular & cut and polished & light blue; green \\
\hline & T.11 & $\mathrm{Z} 11 / 31 \cdot 3$ & $\mathrm{~B}$ & Faience & 1 & tubular & polished & light blue; green \\
\hline & T.12 & $\mathrm{Z}_{12} / 2$ & $\mathrm{~B}$ & Mollusc shell; Cypraea annulus sp. & 1 & & & \\
\hline $4 \cdot 7$ & T.12 & $\mathrm{Z} 12 / 82.1$ & B & Faience & 1 & & & \\
\hline \multirow[t]{3}{*}{4.7} & T.12 & $\mathrm{Z} 12 / 82.2$ & B & Glass & 21 & & drawn, rounded ends & green (st) \\
\hline & T.13 & $\mathrm{Z}_{13} / 2.1$ & $\mathrm{~B}$ & Faience & $\begin{array}{l}220 \text { and } 12 \text { frag- } \\
\text { ments }\end{array}$ & $\begin{array}{l}\text { disc and short } \\
\text { tubular }\end{array}$ & glazed & $\begin{array}{l}\text { whitish with traces } \\
\text { of light blue-green } \\
\text { glaze/whitish cores }\end{array}$ \\
\hline & T.13 & $\mathrm{Z}_{13} / 2.2$ & B & Stone & 1 & barrel & burnished & white and black \\
\hline \multirow[t]{3}{*}{$4 \cdot 4$} & T.13 & $\mathrm{Z}_{13} / 3$ & B & Agate? & 1 & spherical & polished & $\begin{array}{l}\text { light yellow; light } \\
\text { red; dark red traces }\end{array}$ \\
\hline & T.13 & $\mathrm{Z} 13 / 30.1$ & B & Faience & 5 & $\begin{array}{l}\text { short and standard } \\
\text { tubular }\end{array}$ & glazed & turquoise \\
\hline & T.13 & $\mathrm{Z}_{13} / 30.2$ & B & Faience & 5 & disc tubular & glazed & $\begin{array}{l}\text { whitish; traces of } \\
\text { blue-green }\end{array}$ \\
\hline 4.4 & T.13 & $\mathrm{Z} 13 / 31$ & B & Stone & 5 & truncated bicone & & dark reddish \\
\hline $4 \cdot 7$ & T.13 & $\mathrm{Z}_{13} / 3^{2}$ & B & Glass & 1 & globular & wound & green $(t)$ \\
\hline 4.2 & T.13 & $\mathrm{Z13} / 33$ & B & Ostrich eggshell & 3 (1 broken) & disc cylinder & burnished & white \\
\hline \multirow[t]{6}{*}{$4 \cdot 7$} & T.13 & $\mathrm{Z} 13 / 34$ & B & Glass & 1 (8 fragments) & oblate & & light green (st) \\
\hline & T.15 & $\mathrm{Z}_{15 / 10}$ & B & Faience & 1 & & & \\
\hline & T.15 & $\mathrm{Z15} / 13$ & B & Faience & 1 & & & \\
\hline & T.15 & $\mathrm{Z} 15 / 33$ & B & Faience & 1 half & & & \\
\hline & T.16 & $\mathrm{Z1} 6 / 5$ & B & Faience & 2 & & & \\
\hline & T.16 & $\mathrm{Z} 16 / 19$ & B & Faience & 65 & short tubular & & $\begin{array}{l}\text { light green/light blue } \\
\text { glaze; white cores }\end{array}$ \\
\hline $4 \cdot 3$ & T.16 & $\mathrm{Z16/20a}$ & B & Agate & 1 & ellipsoidal & $\begin{array}{l}\text { polished; saw marks } \\
\text { across larger hole }\end{array}$ & light red to dark red \\
\hline $4 \cdot 3$ & T.16 & Z16/2ob & B & Agate & 1 & conical & $\begin{array}{l}\text { polished; saw marks } \\
\text { across larger hole }\end{array}$ & light red to dark red \\
\hline $4 \cdot 3$ & T.16 & $\mathrm{Z1} 6 / 2 \mathrm{Oc}$ & B & Agate & 2 & ellipsoidal & polished & light red to dark red \\
\hline $4 \cdot 3$ & T.16 & $\mathrm{Z} 16 / 21$ & B & Stone & 1 & convex cone & polished & black \\
\hline 4.2 & T.16 & $\mathrm{Z} 16 / 22$ & B & Ostrich eggshell & 2 & disc cylinder & burnished & whitish \\
\hline $4 \cdot 3$ & T.16 & $\mathrm{Z} 16 / 23$ & B & Quartz & 1 & ellipsoidal & $\begin{array}{l}\text { perforated from one } \\
\text { end }\end{array}$ & white \\
\hline $4 \cdot 3$ & T.17 & $\mathrm{Z}_{17} / 6$ & B & Quartz & 1 & teardrop pendant & $\begin{array}{l}\text { saw marks across lar- } \\
\text { ger hole }\end{array}$ & red \\
\hline
\end{tabular}


D

$\mathrm{L} / \mathrm{Th} / \mathrm{W}$
HD

Context data
Season References

Chamber 1, central part 2011

Shaft, S part, near damaged blocking wall of chamber 1

Chamber 1, central part 2011

Chamber 1, central part $\quad 2011$

$1.85 ; 1.35 \quad$ Chamber 1, central part 2011

Chamber 1, central part

Chamber 1, central part

$0.8 ; 1.35$

Chamber

Chamber

Chamber

Burial chamber 1

Burial chamber 1

Burial chamber 1

Fill of robber hole

Chamber 1, E part

Chamber 1, E part

SE corner of shaft; near burial chamber

$5 \cdot 9$

$3.07-4.0$

1.3

SE corner of shaft; near burial chamber

1.5

$1.7 ; 1.93$

SE corner of shaft; near burial chamber

8.61

8.21

1.7

Chamber 4; probably part of decoration of a leather case $\mathrm{Z}_{13} / 15$

$3 \cdot 78-4.02$

$2.94-3.94$

1.9

Chamber 4

4.02

2.1

2.09

Chamber 4, central and E part

$2.32 ; 2.2$

Chamber 4

Chamber 4, central part

$\begin{array}{ll}4.5 & 1.9 \\ 5.76 & ?\end{array}$

1.0

1.0

Chamber 4, central part

Fill of shaft

Fill of shaft, S part

Fill of shaft, N part

Shaft, near chamber 1

$\begin{array}{lll}4.0 & 2.77 & 1.55\end{array}$

$4.28 \quad 5.87$

1.55

Chamber 1 (burial chamber), S part, near skull and skeleton

$1.47 ; 1.0$

Chamber 1 (burial chamber), S part, near skull and skeleton

$0.7 ; 0.95$

Chamber 1 (burial chamber), S part, near skull and skeleton

Chamber 1 (burial chamber), S part, near skull and skeleton

Chamber 1 (burial chamber), S part, near skull and skeleton

$1.25 ; 0.8$

Chamber 1 (burial chamber), S part, near skull and skeleton

1.36

$1.15 ; 0.8$

Chamber 1 (burial chamber), S part, near skull and skeleton

$1.9 ; 2.42$

Burial chamber, central part
2011

2011

2007

2007

2007

2009

2009

2009

2013

2013

2013

2009

Then-Obłuska 2016c, Fig. 6

Then-Obłuska 2016c, Fig. 6

2009

2009

Then-Obłuska 2016c, Fig. 4

2009

2011

2011

2011

Then-Obłuska 2016c, Fig. 4

Then-Obłuska 2016c, Fig. 4

(1)

Then-Obłuska 2016c, Fig. 6
Then-Obłuska 2016c, Fig. 6

\section{Then-Obhuska $2016 \mathrm{c}$ Fig. 4}

2009

2009 Then-Obłuska 2016c, Fig. 4

2009 Then-Obłuska 2o16c, Fig. 6

2009

2009 Then-Obłuska 2016c, Fig. 6

2013

2013

2013

2011

2011

2011

Then-Obłuska 2016c, Fig. 3

Then-Obłuska 2016c, Fig. 3

Then-Obłuska 2016c, Fig. 3

Then-Obłuska 2016c, Fig. 3

2011

2011

Then-Obłuska 2o16c, Fig. 3

2009

Then-Obłuska 2016c, Fig. 3 
TABLE 4.1 Catalogue of the beads and pendants (cont.)

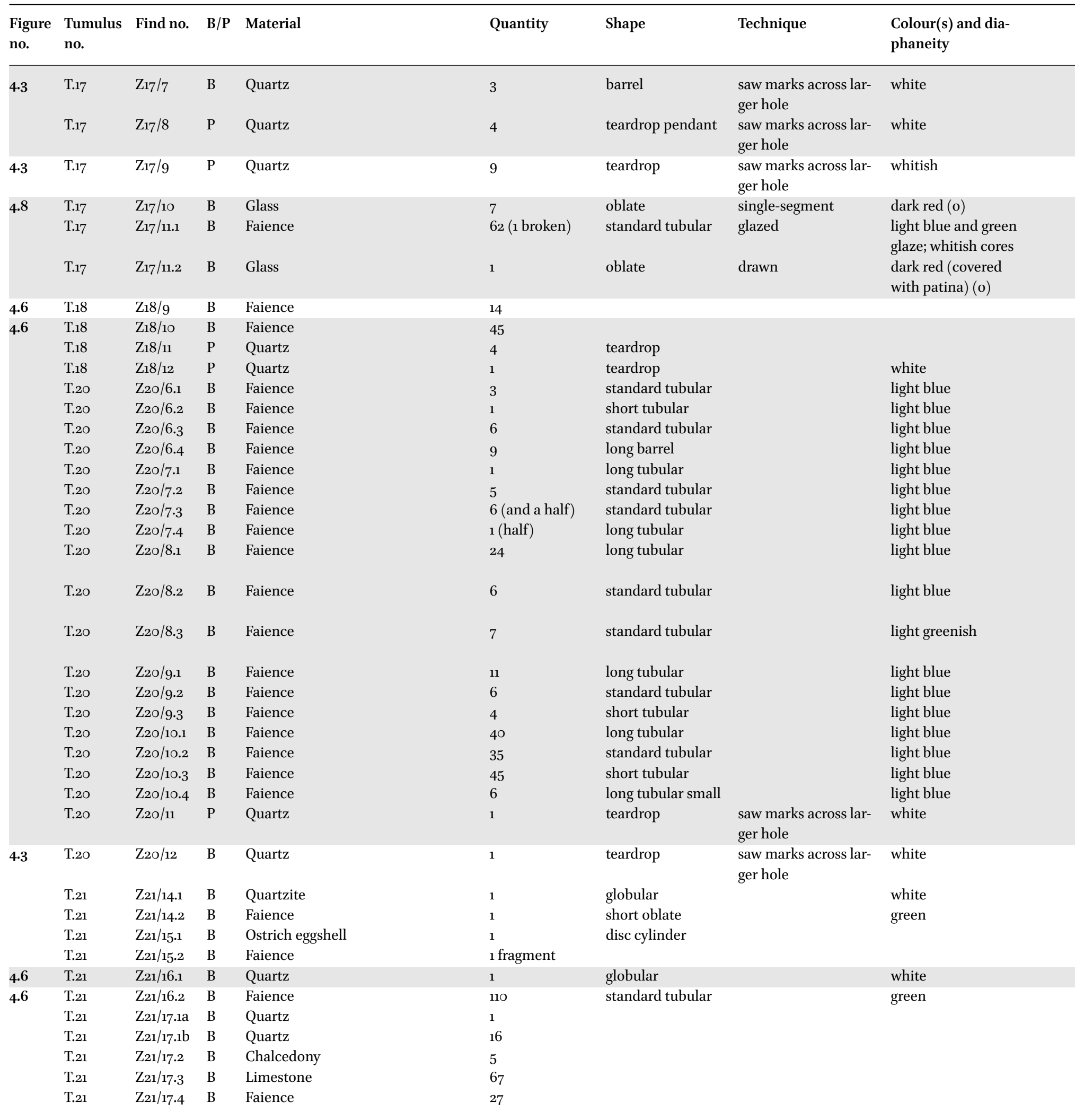


D

$\mathrm{L} / \mathrm{Th} / \mathrm{W}$

HD

Context data

Season References

$7 \cdot 95$

8.84

$11.67 \times 10.46$

15.8

$10.97 \times 9.96 \quad 15.92$

$3 \cdot 36-3 \cdot 73$

$3.46-5.8$

2.3-3.37

c. $3 \cdot 9$

2.38

2.5

$1.38 ; 2.22$

2.06

1.3

2.1

1.1
Burial chamber, S part

Burial chamber, S part

Grave chamber, S part

Grave chamber, S part

Grave chamber

Grave chamber

Central part of shaft, damaged blocking level

Chamber

Shaft, damaged blocking level

Shaft, damaged blocking level

Robber hole, NW part, near stones from damaged blocking wall 2011

Robber hole, NW part, near stones from damaged blocking wall 2011

Robber hole, NW part, near stones from damaged blocking wall 2011

Robber hole, NW part, near stones from damaged blocking wall 2011

Shaft, N part, depth: $0.9 \mathrm{~m} \quad 2011$

Shaft, N part, depth: $0.9 \mathrm{~m} \quad 2011$

Shaft, N part, depth: $0.9 \mathrm{~m}$

Shaft, N part, depth: $0.9 \mathrm{~m} \quad 2011$

Shaft, NE part, near skull and stones from damaged blocking $\quad 2011$ wall

Shaft, NE part, near skull and stones from damaged blocking $\quad 2011$ wall

Shaft, NE part, near skull and stones from damaged blocking $\quad 2011$ wall

Shaft, near bottom $\quad 2011$

Shaft, near bottom $\quad 2011$

Shaft, near bottom $\quad 2011$

Burial chamber $\quad 2011$

Burial chamber $\quad 2011$

Burial chamber $\quad 2011$

Burial chamber 2011

$\begin{array}{lll}3.18 \times 3.08 ; & \text { Burial chamber } & 2011\end{array}$

$1.77 \times 1.8$

$2.88 \times 2.36$; Superstructure (surface)

$1.57 \times 1.37$

Fill of shaft, S part

Fill of shaft, S part 2013

Fill of shaft 2013

Fill of shaft $\quad 2013$

Burial chamber, NW part $\quad 2013$

Burial chamber, NW part $\quad 2013$

Burial chamber, N part $\quad 2013$

Burial chamber, N part $\quad 2013$

Burial chamber, N part $\quad 2013$

Burial chamber, N part $\quad 2013$

Burial chamber, N part $\quad 2013$
Then-Obłuska 2016c, Fig. 3

og

Then-Obłuska 2016c, Fig. 3

9 Then-Obłuska 2016c, Fig. 7

9

o9


TABLE 4.1 Catalogue of the beads and pendants (cont.)

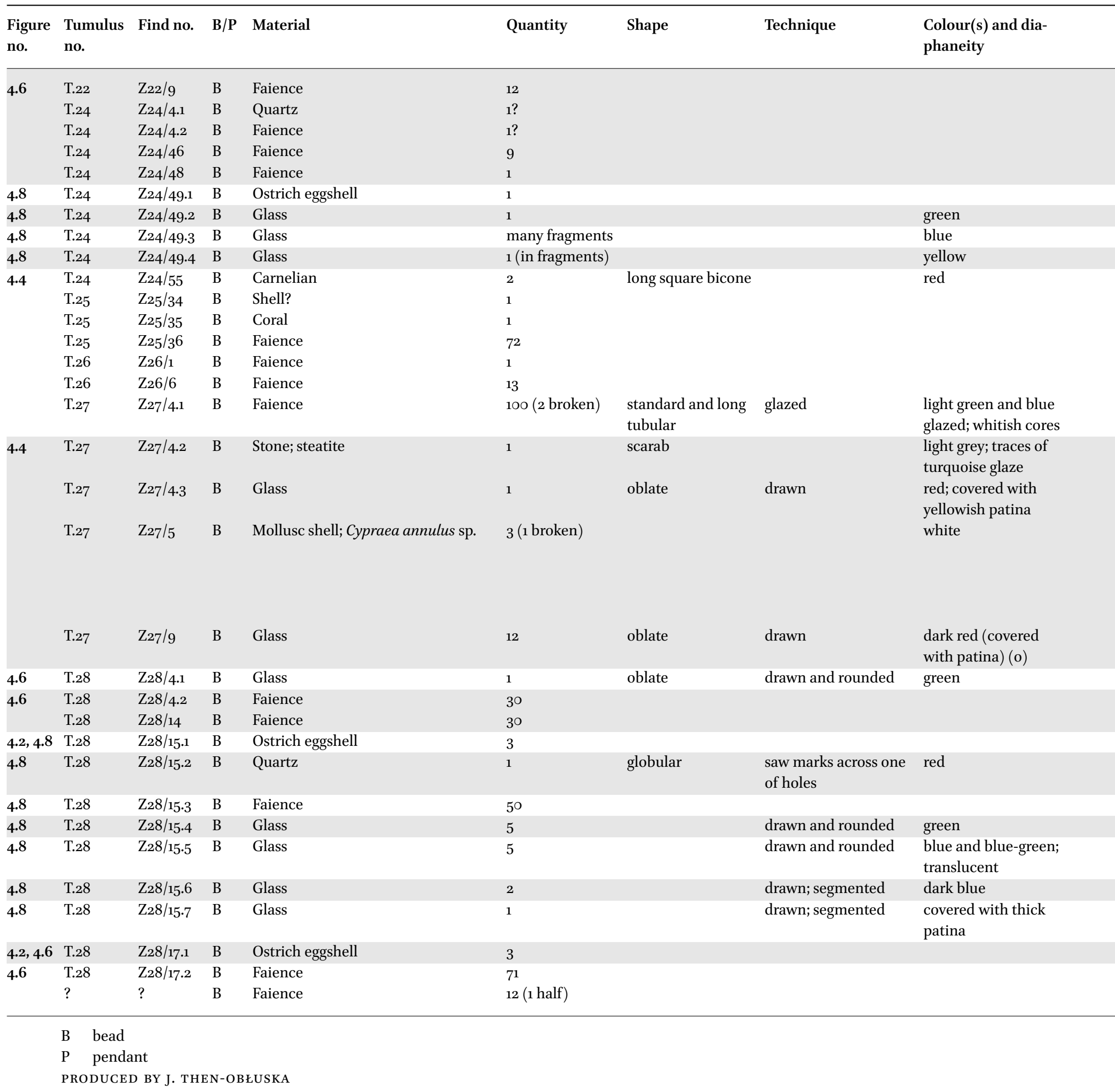


Shaft

Shaft, central and $\mathrm{N}$ part

Shaft, central and $\mathrm{N}$ part

Chamber 1, SE part (E and SE corner)

Sedimentary fill of shaft

Shaft, N part, depth: $1.6 \mathrm{~m}$

Shaft, N part, depth: $1.6 \mathrm{~m}$

Shaft, N part, depth: $1.6 \mathrm{~m}$

Shaft, N part, depth: $1.6 \mathrm{~m}$

Chamber 1, E part (NE corner), next to skeleton

Chamber 1

$10.5 \times 16.9$

Chamber 1

Chamber 1

Shaft (robber hole), N part

Chamber 1, E part, near human bones

$\begin{array}{llll}3.43-5.64 & 2.93-5.87 & \text { c. } 1.7 & \text { Burial chamber, central part }\end{array}$

$1.8 ; 1.9$

Burial chamber, central part

Burial chamber, central part

$5 \cdot 24$
$3 \cdot 52$

3.16

1.0

$15.66 \times$

$15.5^{8 \times 21.87 \times}$

$6.35 ; 15.23 \times$

$20.25 \times 6.6$;

$11.9 \times 17.46 \times$

4.82

$3.1-4.55$

$2.28-3.23$

c. 15
11.25 ;

$14.7 \times 11.0$;

$12.07 \times 9.7$

1.4
Burial chamber, central part

Burial chamber, central part

Shaft, depth: $1.5^{-2} \mathrm{~m}$

Shaft, depth: $1.5^{-2} \mathrm{~m}$

Burial chamber, central part

Burial chamber, S part, near skull

Burial chamber, S part, near skull

Burial chamber, S part, near skull

Burial chamber, S part, near skull

Burial chamber, $\mathrm{S}$ part, near skull

Burial chamber, S part, near skull

Burial chamber, S part, near skull

Burial chamber, $\mathrm{N}$ part

Burial chamber, $\mathrm{N}$ part
2005

2012

2012

2012

2012

2012

2012

2012

2012

2012

2007

2007

2007

2014

2014

2009

2009

2009

2009

2009

2012

2012

2012

2012

2012

2012

2012

2012

2012

2012

2012

2012

2005
Then-Obłuska 2o16c, Fig. 4

Then-Obłuska 2016c, Fig. 2

Then-Obłuska 2016c, Fig. 7

Then-Obłuska 2016c, Fig. 7

Then-Obłuska 2016c, Fig. 7

Then-Obłuska 2016c, Fig. 7

Then-Obłuska 2o16c, Fig. 4

-

Then-Obłuska 2016c, Fig. 5

Then-Obłuska 2016c, Fig. 5

Then-Obłuska 2016c, Fig. 5

Then-Obłuska 2016c, Fig. 5

Then-Obłuska 2016c, Fig. 5

Then-Obłuska 2016c, Fig. 5

Then-Obłuska 2016c, Fig. 5

Then-Obłuska 2016c, Fig. 5

Then-Obłuska 2016c, Fig. 5

Then-Obłuska 2016c, Fig. 5 